\title{
Bridging the gap between industry and academia: Establishing an industry advisory board in Ecuador's higher education system
}

\author{
Hubert B. van Hoof ${ }^{1}$, Alexandra Galarza Torres ${ }^{2}$, Lourdes Sánchez Rodas ${ }^{2}$, María-Isabel Eljuri², \\ Marlene Jaramillo Granda ${ }^{2}$ \\ ${ }^{1} \mathrm{PhD}$, Professor, School of Hospitality Management, Penn State University, Pennsylvania, USA. \\ ${ }^{2}$ MA, Profesor, Facultad de Ciencias de la Hospitalidad, Universidad de Cuenca, Ecuador.
}

Autores para correspondencia: hbv1@psu.edu, alexandra.galarza@ucuenca.edu.ec, lourdes.sanchez@ucuenca.edu.ec, isabel.eljuri@ucuenca.edu.ec, marlene.jaramillo@ucuenca.edu.ec Fecha de recepción: 1 de febrero 2017 - Fecha de aceptación: 4 de marzo 2017

\begin{abstract}
Considering the recent changes regarding curriculum redesign in Ecuador's higher education, as stipulated in the Ley Orgánica de Educación Superior (LOES), this article discusses the benefits of the creation of an industry advisory board in a professional hospitality and tourism management program. Based on a review of the literature, the article argues that an industry advisory board is helpful in creating employment opportunities for students, research opportunities for faculty and engaging alumni in the academic program. Its members can provide academic programs with information on the latest industry trends and assist them in enhancing their community outreach efforts.
\end{abstract}

Keywords: Ecuador, hospitality and tourism, higher education, industry advisory board, Ley Orgánica de Educación Superior.

\section{RESUMEN}

En este artículo se analizan los beneficios de la creación de un consejo asesor de la industria en un programa de gestión de la hospitalidad y el turismo profesional, teniendo en cuenta los recientes cambios en el rediseño curricular de la educación superior ecuatoriana, según lo estipulado en la Ley Orgánica de Educación Superior. Sobre la base de una revisión de la literatura, el artículo argumenta que un consejo de la industria es útil en la creación de oportunidades de empleo para los estudiantes, las oportunidades de investigación para el profesorado y la contratación de antiguos alumnos en el programa académico. Sus miembros pueden proporcionar a los programas académicos información sobre las últimas tendencias de la industria y ayudarles a mejorar sus esfuerzos comunitarios.

Palabras clave: Ecuador, hospitalidad y turismo, educación superior, consejo asesor de la industria, Ley Orgánica de Educación Superior.

\section{INTRODUCTION}

Over the past decade, Ecuador's universities have been impacted by several far-reaching government initiatives intended to improve the overall quality of higher education. These initiatives are meant to shift the country's universities from a "teaching-only" focus to a "teaching-research" perspective and to make them better prepared to meet the country's future socio-economic needs and to improve its global competitive position (Feyen \& Van Hoof, 2013).

The first initiative that greatly affected higher education was the new Constitution of 2008, which established free education for all citizens and sought higher accountability for the country's universities to the central government (Van Hoof et al., 2013). It placed the government firmly in charge of 
university budgets and admission processes and laid the groundwork for the 2010 Higher Education Law. This law, which was the second step in the process of improving higher education standards and performance, further increased the regulation of the universities and greatly decreased their decisionmaking autonomy. Several government offices were created to oversee the process and higher expectations for research productivity at both the faculty and university levels were established (Van Hoof, 2015).

In 2016 was Ecuador's Ley Orgánica de Educación Superior (LOES) reformed resulting in a further change of the landscape of Ecuador's public universities. The reform intent aims classification of all publicly funded Higher Education Institutions (HEIs) into three categories: "teaching," "teaching and research," and "research" universities. The overall objective of the reform is achieving a better fit between the students' skills and abilities and the needs of the country's and private sectors, to enhance the universities' community outreach efforts (the so-called "vinculación con la colectividad") and to achieve greater parity between Ecuador's universities and their counterparts around the world. Concretely, in targeting the universities' teaching missions and their outreach efforts, the new law tasks academic programs to redesign their curricula to better meet the needs of their internal (students) and external (industry and the public sector) stakeholders and enhance their role in society.

In an ideal world, curriculum redesign is a continuous process: once a curriculum is in place, its value and relevance to the field are determined by scanning both internal (students and faculty) and external environments (the public and private sectors, other universities and the global research field in which a program operates) for the latest trends. Based on those assessments, the curriculum is adjusted and the process keeps repeating itself. Yet, this is often not the case in Ecuador's universities as faculty members tend to approach curriculum redesign in a fairly "ivory tower" manner: rather than first envisioning the outcome (What is the profile of the ideal graduate?) or incorporating the needs and opinions of the major stakeholders (What do the students need? What does industry or the public sector expects from graduates?), faculty members modify the curriculum based on long-held beliefs that they know best how to do so. They regard curriculum development and redesign as their prerogative, a sentiment that is bolstered by a lingering perception among many in academia in Latin America that the private sector has a limited role to play in higher education (Aguiló Pérez, 1999; Vega-Jurado et al., 2007). Yet, the opposite is true: information from inside and outside stakeholders is essential in the curriculum redesign process and it has been ignored too long in Ecuador's system of higher education. Input from industry and community leaders is vital in creating a curriculum that is responsive to industry's needs, that provides better opportunities for students and that thereby meets the requirements that the Ecuadorian government has placed on all the public universities in the country.

This article discusses an important component in this process of obtaining information from outside stakeholders, a component that has been virtually non-existent in Ecuador's HEIs up to now, the establishment and incorporation of an industry advisory board as part of the curriculum redesign process. By means of an example based on the Facultad de Ciencias de la Hospitalidad of the University of Cuenca (UC), this blueprint for the development of an advisory board not only calls for incorporating the opinions of external stakeholders in the curriculum redesign process, but also for making the industry advisory board a permanent part of academic program.

All academic programs, but especially those that are directly related to specific industries or fields such as dentistry, tourism, nursing, business, engineering, information technology, education, architecture can benefit from the presence of an advisory board and should obtain industry and community feedback prior to redesigning their curricula. If we do not know what the desired outcome needs to be, how do we know how to get there and how do we know what our curriculum needs to incorporate? 


\section{REVIEW OF LITERATURE}

\subsection{The benefits of an industry advisory board}

Academics in general, and those in Latin America should acknowledge the contributions that the public and private sectors can make to their programs and curricula. Industry executives may not be fully aware of how academia works, they may not realize that academia tends to make decisions by consensus rather than by decree, and they may not fully understand why decision-making in academia tends to be much slower than in the private sector. Yet, they represent the industries that will employ their students and the companies that hire them. Industry executives have a much greater awareness of the most recent trends in industry than academics: whereas academics mostly read about an industry, practitioners live it every day!

Advisory boards are selected and appointed to provide programs with expert advice (Conroy et al., 1996). They are not governing boards and therefore have no formal decision making responsibilities. Their activities could relate to professional development, research support, curriculum design, resource acquisition and setting a strategic direction for the program (Olson, 2008; Nagai \& Nehls, 2014)). At times, they can wield considerably more influence with the administration of the program and/or the university where individual faculty members cannot, when some of the board members are also donors to the university and thereby serve as strong advocates of faculty initiatives (Andrus \& Martin, 2001; Henderson, 2004; Athavale et al., 2010).

Whereas they are not common in Latin American higher education and non-existent in Ecuador, college advisory boards are very common in programs in higher education around the world and they exist in many different disciplines, especially in professional programs. One of the major challenges professional programs are faced with is keeping up with the changes that occur in the field and advisory councils can establish a vital link between academia and the business world (Henderson, 2004; Ellingson et al., 2010). They can help academic programs by means of community and industry relations, internships, speaking engagements, jobs and leadership skill development for students (Dorazio, 1996; Kaupins \& Coco, 2002; Avila et al., 2005; Rose \& Stiefer, 2013). If managed properly, they can be of great political and practical value to academic programs (Newman, 2010).

Examples of the use of advisory boards in different academic fields of study are plentiful. Their contributions have been described in areas such as journalism (Henderson, 2004), nursing (McNamara et al., 2010), communication (Penrose, 2002; Rose, 2006; Benigni et al., 2011), education (Hammond \& Moser, 2009), engineering (Rooney \& Puerzer, 2002; Coe, 2008; Genheimer \& Shehab, 2009), business (Andrus \& Martin, 2001; Kaupins \& Coco, 2002; Athavale et al., 2010; Ellingson et al., 2010) and information technology (McGill et al., 2012; Pilgrim, 2013; Mandviwalla et al., 2015). In the hospitality and tourism field, their chief role has been described as offering advice to administrators and faculty on such issues as curriculum content, internships, fundraising, strategic planning and job placement (Conroy et al., 1996). Besides their advisory role, they also "enhance the program's image, advocate for the program, and develop resources for the program" (Conroy et al., 1996, p.87).

Ultimately, it comes down to the truth that academics produce the talent and industry practitioners utilize it. Both groups stand to gain greatly through well-educated students and stand to lose just as much when students are poorly educated and poorly prepared for the realities of the workplace (Lefever \& Withiam, 1998). A continuous, open dialogue in the form of a permanent advisory board is a way to make this a win-win situation for both parties.

\subsection{The different roles of the advisory board}

Advisory boards may differ in size, role, and structure. Mandviwalla et al. (2015) identified four different board roles or "archetypes": "Ceremonial, Forum, Mentor and Partner" (p. 23). These roles are not set in stone and may change over time. The first two archetypes tend to be less engaged and may be partially explained as serving board members just as much as the academic program. A Ceremonial Board, as the name suggests, does not necessarily focus on operations. It is comprised of high-profile individuals who have the means and the willingness to invest in the program and the university. A Forum Board is a group that "facilitates knowledge and human capital exchange ... a platform for 
sharing ideas and networking ... and accommodates diverse value propositions" (Mandviwalla et al., 2015, p.23).

Mentor and Partner boards tend to be much more engaged in the academic programs they support. A Mentor Board focuses on engagement with students and faculty members: board members are actively engaged in program review and curriculum design and seek out opportunities to interact with students and assist them in their professional development. In other words, they take their mentorship responsibilities very seriously. Finally, a Partner Board has the highest level of collaboration and the most intense partnership with the academic program: it may engage in curriculum and program review, participate in faculty research activities, co-chair events such as workshops and conferences and engage in social events with students and faculty (Mandviwalla et al., 2015).

Coe (2008) proposed another way of looking at the different roles of the advisory board. He suggested that boards could be either "proactive" or "passive". Following this author, a "passive" board "confines itself to requests from the school ... is briefed on certain projects, participates in a tour of the facilities, views a student demonstration, is hosted to a meal and is frequently asked to help fund the most recent department project" (p. 7). A "proactive" board, on the other hand, initiates suggestions or comments that are "generated from experiences of board members" (p. 7).

\subsection{Board membership}

Authors on the topic largely agree on board membership and size. Conroy et al. (1996) suggest that a 15-20-member board is a workable size: it is not too large to become unwieldy and difficult to control and not too small that absences at meetings become debilitating and others have supported this number (Kaupins \& Coco, 2002) as well. Board members tend to be recruited among experts in the field, higherlevel executives, engaged alumni interested in coming and giving back, employers of program graduates, political and community leaders, public sector executives and even students (e.g. Conroy et al., 1996; 2008; Ellingson et al., 2010; Newman, 2010; Rose \& Stiefer, 2013; Mandviwalla et al., 2015).

A second important membership-related issue is the selection of the chair of the board. A wellfunctioning advisory board is led by a chairperson who is passionate about both industry and academia, who is highly regarded by his/her peers in the field and by the local community (Mandviwalla et al., 2015). This person should have the time and willingness to be in regular contact with the program's administration, over and above the regular board responsibilities, and take close personal and professional interest in the well-being of the students and the faculty.

\subsection{Pitfalls to avoid}

Even though advisory councils tend to be regarded favorably in most of the literature on the topic, some issues have been raised that need to be avoided. As stated earlier, the role of a board is advisory, first and foremost and it should be made clear from the start that the board does not govern. It should accept that the academic program and its leadership can take, or leave, its advice (Conroy et al., 1996). If a board is allowed to govern, the risk is that the leadership and management styles that are common in industry and academia will clash, which will lead to mutual frustration: "senior executives expect immediate top-down implementation, whereas universities operate more slowly and often by consensus" (Mandviwalla et al., 2015, p. 25). Board members should realize that their efforts, however well-informed and well-intended, are ultimately only advice and nothing more.

Another important issue regarding the effectiveness of the advisory board is the communication with faculty and students. It is a common practice for only a few faculty representatives and program administrators to interact with the board. Most faculty members are informed through feedback from the administration. This not only means that the perception of the board among faculty members is tainted by the way in which board decisions and contributions are communicated, but also that faculty members who are not part of the process will quickly feel excluded. As Kilcrease (2011) found, faculty members who do not attend board meetings or who do not interact with its members tend to discard the value of its contributions and frown upon suggestions that were made, perhaps not because they were not good suggestions, but rather because they were not part of the process. Similarly, students who are, by nature, far removed from the board members, cannot be expected to be engaged with the board or 
receptive to the advice of its members if they have limited or no interaction with the board at all (Benigni et al., 2011).

A third common pitfall to avoid is not to have a clear mandate for the board to work with. Mandviwalla et al. (2015) advocate that the board be given clear mission and objectives statements to structure its conversations and contributions. Similarly, Conroy et al. (1996) also state that the board should not be engaged in faculty-related matters which should be dealt with in departmental or faculty meetings. As Genheimer \& Shehab (2009) suggest, effective boards have a clear understanding of their roles and understand their limitations in influencing the future direction of the academic program.

Most of the literature on the topic of university advisory boards suggests a higher presence in business and other professional programs. Perhaps, as Rose \& Stiefer (2013) state, this is due to the nature of the program and based on the idea that these programs prepare future business leaders, who are in fact the people who may come to serve on the advisory boards of the future. Yet, the usefulness of an advisory board can certainly go beyond the realms of professional programs such as nursing, business or engineering. Why could an advisory board of high school administrators and English language teachers not be just as useful to an English Language Department, just like a board consisting of artists, architects, city planners, government officials and art association executives could be very helpful for a Department of Arts and Architecture?

\section{DISCUSSION}

\subsection{Preliminary step: Determining what industry thinks}

Given the fact that program advisory boards are very rare in Ecuadorian higher education, the introduction of an advisory board needs to be a gradual and careful process, involving both patience and goodwill on both sides. Program faculty and administrators need to become accustomed to the idea that industry executives will provide input in the curriculum and that they can play an important role in setting the strategic direction of the program. Conversely, industry board members need to become familiar with decision making processes in academia and get used to the idea that they are only "advisors" and that the program can take or leave their advice. As board members, they are not the decision makers like they are in their own businesses, they are only advisors and mentors.

As stated earlier, in academic circles in Latin America there has long been considerable resentment about industry involvement in curriculum design (Vega-Jurado et al., 2007). The curriculum is regarded the faculty's prerogative and many professors feel that the role of the private sector should be limited in that process. Yet, industry executives are much more aware of the latest trends in industry and they are the "consumers" of the final product that academic programs produce: the graduating student. It is safe to say that curricula become dated quickly and that textbooks not always reflect the latest trends: the moment a textbook comes out after a writing process that takes a few years, its content is already dated. If professors keep repeating their lectures for a few years in a row and continue to use the same textbook and not use additional, up-to-date resources, they exacerbate the problem and they will graduate students who are not optimally prepared for the realities of the workplace.

A good first step in the development of an industry advisory board in the area hospitality and tourism management is to get a sense of what the industry thinks about the academic program before inviting executives to serve on an advisory board. In the case of the Facultad de Ciencias de la Hospitalidad at the UC, a study on industry perceptions about hospitality and tourism education in Ecuador (Van Hoof et al., 2014) uncovered valuable information that will be now be included in the process. The study, which was based on group interviews with tourism and hospitality executives in Quito, Guayaquil and Cuenca, first found that there was a universal appreciation of the value of the degree. Yet, participants emphasized that a college degree needed to be combined with practical work experience. It was mentioned that past hires with hospitality and tourism degrees tended to have inflated career and salary expectations, as was also found by Lefever \& Withiam (1998), that they had limited quantitative and problem-solving skills, and that they lacked fluency in foreign languages, a common problem among Ecuador's students. 
According to these executives, the ideal graduate, who is the "outcome" or "goal" of any hospitality/tourism program, should be a proactive, creative thinker with the service orientation and emotional intelligence to become successful. He/she possesses the ability to communicate in multiple foreign languages and is a critical, analytical thinker. Yet, more than anything, this ideal graduate has work-experience, which was a re-occurring theme in the discussions. Work experience can be gained in industry internships and executives favored semester-long, rotational work experiences that were very different from the short, two- to four-week part-time internships that are common at present and that are based on the academic program's needs and timelines, not the industry's. Industry executives looked for much better coordination and communication from the universities and for students to accept the fact that life at times revolves around work and not the other way around.

Finally, when asked what they thought about the relationship between industry and academia, these executives showed themselves highly interested in a more permanent, strategic alliance that involved regular, intense communication. They felt that, where they could contribute internships, jobs and ultimately careers for students and academic programs could contribute with executive education, research support and job candidates for the industry (Van Hoof et al., 2014).

\subsection{The creation of an advisory board}

Based on the needs of the program, a review of relevant literature and the opinions of hospitality executives around the country, the creation of an advisory board, although slow and labor-intensive, could look as follows: a very important first step would be to determine the nature and the role of the board. Given the interest among hospitality and tourism industry executives to be a part of the program, this article advocates for a pro-active, "mentor" board, not only because it enables members to provide suggestions and advice on their own accord, but also because it generates a much closer involvement in the program and greater engagement with students, faculty and program administration. Given the nature of the Facultad de Ciencias de la Hospitalidad, which has programs of studies in Gastronomy, Tourism and Lodging Management, a 15-20-member advisory board with representatives from each of the sectors is created; it may have three sub-groups for each of the industry sectors.

The chair of the board, an industry executive with broad experience and exposure to many facets of the industry and the local community, but also with a strong appreciation for the value of education and research, will be the first concrete step in the selection of board members. This person will be in close and regular communication with the leadership of the program and will assist in identifying and inviting additional board members. In the case of Cuenca, the profile of an ideal chairperson would be an industry executive who serves on local industry associations and who has been engaged in university functions such as guest lectures and social events. Additional board members can be selected based on their interest in academia, their stature in industry and the community, but also because they bring "something special" to the table. Outspoken critics of academia should not be avoided, since it is just as important to hear what is wrong with the curriculum or the program as it is to hear what is right. As this is a first step, initial board members will be recruited from the local hospitality and tourism industries: it is unreasonable to expect executives to travel to Cuenca from Quito or Guayaquil for a board meeting. Moreover, local executives can be expected to have greater awareness of the program as they may have hired in the past UC's graduates and therefore they will be more inclined to attend board meetings regularly and to contribute to the best of their abilities.

Potential board members who are often overlooked as sources of information and employment in the Latin American academic environment are the program's alumni. The Facultad de Ciencias de la Hospitalidad could invite former students who have entered the industry to serve on its board. Alumni will not only be highly dedicated and engaged board members; they are also very knowledgeable about the program and its curriculum. They have been shown extensively in the literature to provide useful information about the quality and relevance of the program in industry and how the skills they acquired as students transferred into the workplace (McCleary et al., 1989; Pavesic, 1993; Weerts \& Ronka, 2007; Weerts \& Ronka, 2008; Egan \& Cockill, 2012). At present, the Facultad de Ciencias de la Hospitalidad is not actively engaged in tracking the careers of its former students, and incorporating some of them in the advisory board will also prove to be beneficial in establishing an alumni network. Finally, the program can decide whether to invite or not its own students to be part of the board. Faculty 
members, however, cannot serve as members of the board, but could participate as presenters or observers during board discussions.

Once installed, advisory board members will be provided with a mandate and a clear set of expectations. A first expectation is that board members participate in meetings on a bi-annual (every semester) basis and that they come to the meetings prepared, having read materials sent to them ahead of time. The chair of the board serves as the conduit between the program administration/faculty and the board members and will work with the administration on drafting board guidelines. As part of the guidelines, board members will be told what their role is and that, upon acceptance of their appointment, they agree to represent the academic program to the outside world and serve as its champions. All other details regarding meeting times and frequency and topics for discussion are left to the discretion of the board and the program's administration.

Topics for discussion and review should be presented to the board by the academic program, yet board members should be encouraged to suggest topics for discussion as well, in line with their roles as "mentors". Whereas the first meeting is anticipated to be introductory, with an overview of the program and its faculty, subsequent meetings could focus on curriculum, internships, research and the overall strategic direction of the program. The latter is one of the most important tasks of the board, yet for that to be done in an efficient and effective way board members need to be familiar with the program and the curriculum, reason why it cannot be the topic of a first meeting. Even though the responsibility for the board's agenda lies with the program director, it is advisable that one additional person in the program is placed in charge of communication with the board. This position, a "Director of Industry Relations," could also be placed in charge of all internships, career placements and alumni relations.

\subsection{Potential outcomes}

If managed well and given a clear mandate, an industry advisory board can be a powerful ally in any professional program in academia. Besides many of the benefits described above, board members can be asked, or perhaps even expected, to host interns for longer periods of time. Given the members' close relationship with the hospitality and tourism program, student-interns can count on worthwhile experiences and board members can expect close collaboration and clear communication on the part of the university, something they expressed as lacking in the present format of internship programs. Highquality internships will also address the concern of Ecuador's government that programs are not practice-oriented enough and that they need to bring academia and practice closer together.

Faculty members can involve board members in their research efforts. As industry executives become more familiar with academia, they will gain a greater appreciation of the value of research and will realize how difficult it is, for faculty to collect good data to work with. Whereas faculty members gain because they are expected to conduct research and to publish, industry gains by using faculty members to address some of their problems and answer some of the questions they are confronted with. This could eventually lead to an annual conference, for instance, which brings industry and academia together around industry's most pressing problems.

Regarding the students, every board meeting should be accompanied by social events that bring faculty, students and board members together in an informal setting. Students will gain from these events by developing their networking and interpersonal skills and they can use them to secure internships and jobs. Board members benefit from being able to "pre-select" the most promising job candidates based on their social skills and faculty members gain as they see their students gain employment. Board members can be asked to serve as guest lecturers to present students with the most up-to-date industry issues, to serve as guest chefs and judges in culinary events, and as mentors in reviewing student resumes and in practicing their interview skills.

\section{CONCLUSION}

Ecuador's government is asking academia to change the ways in which it does research and educates its students. In both research and teaching, the changes that it proposes should lead to a greater 
responsiveness by the universities to the country's socio-economic needs and to students who are better prepared to meet the demands of the modern workplace. The creation of an industry advisory board as discussed here is a small but vital step in assuring that a curriculum is up-to-date and industry-relevant. Closer collaboration with public and private organizations can lead to enhanced research opportunities for faculty members, and students will have better internship experiences and better opportunities to secure good jobs because they have more realistic career expectations and have combined an academic degree with solid work experience. An additional benefit of the creation of an industry advisory board is that it will help in bringing the academy closer to the community in which it operates, thereby addressing the government's requirement of greater involvement with the outside community, the "vinculación con la collectivad."

Even though much of the literature on the topic is related to the functioning of advisory boards in professional programs, there is no reason to assume that a board of advisors would not be beneficial in any academic program. Its role might be different, and board members may not always have internships or jobs to give away, but that does not mean that practitioners in other fields cannot be valuable resources in other ways: they can suggest research topics, they can share the most modern practices and present the most pressing problems in the field, they can serve as mentors, and they can certainly help in setting the strategic direction of a program.

For too long, academics in Latin America in general, and in Ecuador have felt that there is only a limited role for industry to play in academia. It is time for them to step down from their ivory tower and accept that industry and community members outside academia can and need to provide valuable input and that they can be valuable resources to a program, any program. Regardless of whether the government has now issued mandates regarding academic research, faculty qualifications and program curricula, it is time for academic programs in Ecuador to do what so many outstanding academic programs around the world have been doing for so long: create an industry advisory board and listen to what these interested and dedicated outsiders have to say.

\section{REFERENCES}

Aguiló Pérez E (1999). Consideraciones en torno a los trabajos y investigaciones sobre calidad en la formación turística. Cuadernos Turismo 4:7-19

Andrus DM, Martin D (2001). The development and management of a department of marketing advisory council. Journal of Marketing Education 23(3):216-227

Athavale M, Myring M, Davis R, Truell A (2010). Factors influencing success in integrating the fouryear business school curriculum: Implications for business educators. The Journal of Research in Business Education 52(1):4-15

Avila SM, Bratton JC, Baur MN (2005). Developing an advisory board to enhance collegiate finance programs. Journal of Financial Education 31:1-13

Benigni V, Ferguson D, McGee B (2011). Establishing a "renown-gown" relationship: The role of advisory boards in communication programs. Journalism \& Mass Communication Educator 66(1):54-68

Coe JJ (2008). Engineering advisory boards: Passive or proactive? Journal of Professional Issues in Engineering Education and Practice 134(1):7-11

Conroy PA, Lefever MM, Withiam G (1996). The value of college advisory boards. Cornell Hotel and Restaurant Administration Quarterly 37(4):85-89

Dorazio P (1996). Professional advisory boards: Fostering communication and collaboration between academe and industry. Business Communication Qaurterly 59(3):98-104

Egan D, Cockill J (2012). Enhancing student learning and development in cooperation with our alumni. Student Engagement and Experience Journal 1(1):1-12

Ellingson DA, Elbert DJ, Moser S (2010). Advisory councils for business colleges: Composition and utilization. American Journal of Business Education 3(1):1-8 
Feyen J, Van Hoof HB (2013). An analysis of the relationship between higher education performance and socio-economic and technological performance indicators: A Latin-American case study. Maskana 4(2):1-20

Genheimer SR, Shehab RL (2009). A survey of industry advisory board operation and effectiveness in engineering education. Journal of Engineering Education 99(2):169-180

Hammond KL, Moser E (2009). Curriculum advice from your advisory board: A survey instrument. Academy of Educational Leadership Journal 13(3):59-72

Henderson JK (2004). A survey of advisory board ABSs... advice, balance, and charge. Journalims and Mass Communication Educator 59(1):60-76

Kaupins G, Coco M (2002). Administrator perceptions of business school advisory boards. Education 123(2):351-358

Kilcrease KM (2011). Faculty perceptions of business advisory boards: The challenge for effective communication. Journal of Education for Business 86(2):78-83

Lefever MM, Withiam G (1998). Curriculum review: How industry views hospitality education. Cornell Hotel and Restaurant Administration Quarterly 39(4):70-78

Mandviwalla M, Fadem B, Goul M, George JF, Hale DP (2015). Achieving academic-industry collaboration with departmental advisory boards. MIS Quarterly Review 14(1):17-35

McCleary KW, Lepisto LR, Damitio JW (1989). Alumni involvement with hospitality programs: Dedication and dollars. Journal of Hospitality and Tourism Research 13(3),541-543

McNamara A, Roat C, Kemper M (2012). Preparing nurses for the new world order: A faculty development focus. Nursing Administration Quarterly 36(3):253-259

McGill T, Armarego J, Koppi T (2012). The teaching-research-industry learning nexus in information and communications technology. ACM Transactions on Computing Education 12(1),1-20

Nagai J, Nehls K (2014). Non-alumni board volunteers. Innovative Higher Education 39(1):3-16

Newman S (2010). Indispensable traits of high performance advisory committees. Industry and Higher Education 24(1):11-15

Olson GA (2008). The importance of external advisory boards. Chronicle of Higher Education 54(24), C3

Pavesic DV (1993). Hospitality education 2005: Curricular and programmatic trends. Journal of Hospitality and Tourism Research 17(1):285-294

Penrose JM (2002). Strengthen your business communication program with an alumni advisory board. Business Communication Quarterly 65(4):73-84

Pilgrim CJ (2013). Industry involvement in ICT curriculum: A comparative study. Proceedings of the 2013 International Conference on Software Engineering, pp. 1148-1153

Rooney DM, Puerzer RJ (2002). The smaller engineering school and it industrial advisory board: An effective partnership. Frontiers Educaction 2:F1B-16-F1B-21

Rose JM (2006). Using a alumni interview to promote rhetorical sophistication. Business Communication Quarterly 69(3):284-292

Rose KJ, Stiefer TW (2013). Advisory councils in executive education: Insights from practice. Journal of Executive Education 12(1):1-12

Vega-Jurado JM, Fernández-de Lucio I, Huanca-López R (2007). La relación universidad-empresa en América Latina: Apropriación incorrecta de modelos foráneos. Journal of Technology Management and Innovation 2(3):97-109

Van Hoof HB (2015). Ecuador's efforts to raise its research profile: The Prometeo grant program. Journal of Hispanic Higher Education 14(1):56-68

Van Hoof HB, Cueva A, Estrella M, Torres L, Eljuri MI (2014). Percepciones del sector empresarial sobre la educación de hospitalidad, gastronomia y turismo en el Ecuador. CULTUR 8(1):211-238

Van Hoof HB, Estrella M, Eljuri MI, Torres L (2013). Ecuador's system of higher education in times of change. Journal of Hispanic Higher Education 12(4):345-355 
Van Hoof HB, Verbeeten MJ, Estrella M (2015). Toward a hospitality management curriculum of the future: Addressing Ecuador's student and industry needs. Atlante-Cuadernos de Educación y Desarollo 55:1-15

Weerts DJ, Ronca JM (2007). Profiles of supportive alumni: Donors, volunteers and those who "do it all." International Journal of Educational Advancement 7(1):20-34

Weerts DJ, Ronca JM (2008). Characteristics of alumni donors who volunteer at their alma mater. Research in Higher Education 49(3):274-292 